\title{
EZH2: a novel target for cancer treatment
}

\author{
Ran Duan ${ }^{1,2+}$, Wenfang Du ${ }^{3+}$ and Weijian Guo ${ }^{1,2^{*}}$ (i)
}

\begin{abstract}
Enhancer of zeste homolog 2 (EZH2) is enzymatic catalytic subunit of polycomb repressive complex 2 (PRC2) that can alter downstream target genes expression by trimethylation of Lys-27 in histone 3 (H3K27me3). EZH2 could also regulate gene expression in ways besides H3K27me3. Functions of EZH2 in cells proliferation, apoptosis, and senescence have been identified. Its important roles in the pathophysiology of cancer are now widely concerned. Therefore, targeting EZH2 for cancer therapy is a hot research topic now and different types of EZH2 inhibitors have been developed. In this review, we summarize the structure and action modes of EZH2, focusing on up-todate findings regarding the role of EZH2 in cancer initiation, progression, metastasis, metabolism, drug resistance, and immunity regulation. Furtherly, we highlight the advance of targeting EZH2 therapies in experiments and clinical studies.
\end{abstract}

Keywords: EZH2, H3K27me3, Cancer, EZH2 inhibitor

\section{Background}

Transcription is important in cell fate decision. Dysregulation of transcription is a determinant of cancer phenotype. In addition to genetic alteration, abnormal epigenetic regulation of transcription plays an important role in carcinogenesis and cancer development.

Enhancer of zeste homolog 2 (EZH2) is a member of the family of polycomb group genes (PcGs), which is a group of important epigenetic regulators that repress transcription. Polycomb repressive complex 2 (PRC2) is one of the two PcG proteins core complexes and mediates gene silencing mostly by modulating chromatin structure [1]. EZH2 is an enzymatic catalytic subunit of $\mathrm{PRC} 2$ that can alter gene expression by trimethylation of Lys-27 in histone 3 (H3K27me3) [2]. H3K27me3 is associated with repression of genes expression and regarded as a critical epigenetic event during tissue development and stem cell fate determination [3]. Besides H3K27me3,

\footnotetext{
* Correspondence: guoweijian1@hotmail.com

${ }^{\dagger}$ Ran Duan and Wenfang Du contributed equally to this work.

'Department of Medical Oncology, Fudan University Shanghai Cancer Center, Shanghai 200032, People's Republic of China

${ }^{2}$ Department of Oncology, Shanghai Medical College, Fudan University, Shanghai 200032, People's Republic of China

Full list of author information is available at the end of the article
}

PRC2 also methylates non-histone protein substrates, including the transcription factor GATA4 [4]. In addition, EZH2 methylates non-histone targets or directly interacts with other proteins to activate downstream genes in a PRC2-independent manner [5-7].

Via the above 3 ways, EZH2 works as a master regulator of cell cycle progression [8], autophagy, and apoptosis [9], promotes DNA damage repair and inhibits cellular senescence [10] and plays an important role in cell lineage determination and relative signaling pathways [11]. EZH2 functions in such various biological processes, which is the reason why it is related to many diseases, including cancer. The associations between EZH2 and cancer initiation, progression, metastasis, metabolism, drug resistance, and immunity regulation are key points discussed in this review (Fig. 1).

As there are many important roles of EZH2 in cancer, therapies targeting EZH2 have been important strategies in treatment of many types of cancer. This review discussed in detail about inhibitors of EZH2 methyltransferase activity, inhibitors that break PRC2's structure, suppressing EZH2 through triggering EZH2 degradation, and the combination of EZH2 inhibitors with other treatment methods. 


\begin{tabular}{|c|c|c|c|c|}
\hline Mechanisms of actio & & Biological functions & & Roles of EZH2 in cancer \\
\hline $\begin{array}{l}\text { PRC2-dependent } \\
\text { H3K27 methylation }\end{array}$ & \multirow[b]{4}{*}{ Methylation } & \multirow{3}{*}{$\begin{array}{l}\text {-Regulating cell } \\
\text { cycle, autophagy, } \\
\text { apoptosis and } \\
\text { cell senescence } \\
\text {-Promoting DNA } \\
\text { damage repair }\end{array}$} & \multirow{3}{*}{$\begin{array}{l}\text { Mutation/ } \\
\text { abnormal } \\
\text { expression }\end{array}$} & $\begin{array}{l}\text { Initiation (oncogene or } \\
\text { tumor suppressor) }\end{array}$ \\
\hline \multirow{2}{*}{$\begin{array}{l}\text { PRC2-dependent } \\
\text { non-histone protein } \\
\text { methylation }\end{array}$} & & & & Metastasis \\
\hline & & & & Immunity \\
\hline \multirow{3}{*}{$\begin{array}{l}\text { PRC2-independent } \\
\text { gene transactivation }\end{array}$} & & & & Metabolism \\
\hline & \multirow{2}{*}{$\begin{array}{l}\text { Methylation- } \\
\text { independent }\end{array}$} & & & \multirow[t]{2}{*}{ Drug resistance } \\
\hline & & & & \\
\hline \multicolumn{5}{|c|}{$\begin{array}{l}\text { Fig. } 1 \text { Mechanisms of action, functions, and abnormal changes of EZH2. EZH2 functions in various biological processes via } 3 \text { types of mechanism } \\
\text { including PRC2-dependent H3K27 methylation, PRC2-dependent non-histone protein methylation, and PRC2-independent gene transactivation. } \\
\text { When mutation or abnormal expression happens, EZH2 is related to cancer initiation, metastasis, immunity, metabolism, and drug resistance }\end{array}$} \\
\hline
\end{tabular}

\section{Structure of EZH2}

$\mathrm{EZH} 2$ gene is mapped to chromosome 7q35, including 20 exons coding 746 amino acid residues [12]. There are five domains, including EED-interaction domain (EID), Domain I, Domain II, cysteine-rich domain (CXC domain), and C-terminal suppressor of variegation 39, enhancer of zeste and trithorax domain (SET domain) [2, 13]. The histone methyltransferase activity of EZH2 is mainly maintained by SET domain, CXC domain $\mathrm{N}$ terminal to the SET domain is also required. The Nterminal domains are the protein interaction domains, which are required for the assembly of partner subunits of proper PRC2 functions [2].

\section{Action modes of EZH2}

EZH2 acts as a histone methyltransferase mainly by its SET domain, and it could suppress or co-activate transcription in a PRC2 dependent or independent way.

\section{PRC2-dependent $\mathrm{H} 3 \mathrm{~K} 27$ methylation}

Histone, located in the center of nucleosome, is not just a packing protein, but a dynamic functional interface between DNA and other cell components. After histone modification, the chromosome structure changes. The enzyme that catalyzes histone modification in cells can transfer the information it carries to the chromosomal regulator, which eventually leads to the change of gene expression [14].

As a subunit of PRC2, EZH2 trimethylate H3K27 in the nucleus. PRC1 binds to PRC2-modified H3K27me3 and monoubiquitinylates histone $\mathrm{H} 2 \mathrm{~A}$ at lysine 119 , which could facilitate chromatin compaction, and therefore promote downstream genes transcriptional silencing
[15]. P21 is a key tumor suppressor gene, which inhibits cell proliferation by suppressing CDK. EZH2 could bind to P21 promoter region and mediate H3K27me3 modification, resulting in transcriptional silencing of P21, and promoting proliferation of gastric cancer cells [16].

\section{PRC2-dependent non-histone protein methylation}

Besides histone, EZH2 also methylate non-histone proteins in a PRC2-dependent way. For example, EZH2 could methylate cardiac transcription factor GATA4 at Lys299 to decrease p300-mediated GATA4 acetylation and represses GATA4 transcription [4].

\section{PRC2-independent gene transactivation}

EZH2 could activate downstream genes in a PRC2independent way by direct methylation of non-histone proteins. AKT phosphorylates EZH2 at Ser21. STAT is a transcriptional factor, the phosphorylated EZH2 could methylate STAT3 to activate STAT3 signaling [5]. This PRC2-independent action mode was first found in castration-resistant prostate cancer (CRPC). In CRPC cells, phosphorylated EZH2 activates AR, which is a transcription factor, through a PRC2-independent but methylation-dependent mechanism. This activation of AR promotes transcription of its downstream genes and supports CRPC growth [6].

However, the most recent study revealed that EZH2 could play a non-catalytic role in CRPC cells in a PRC2and methylation-independent way. EZH2 could directly activate AR gene transcription through occupying its promoter, which could not be blocked by enzymatic EZH2 inhibitor [7]. 


\section{Roles of EZH2 in cancer}

Many members of PcG family play important roles in cancer, including Bmi-1 [17], Mel-18 [18], CBX7 [19], and EZH2. As previously described, EZH2 regulates its downstream genes and proteins by PRC2-dependent or PRC2-independent methylation or in a PRC2- and methylation-independent way, which are the basic mechanisms it works and shows so many functions mentioned before. However, when mutation happens or expression is abnormal, including overexpression, downregulated expression, and expression loss, it is related to cancer initiation, progression, and metastasis.

\section{Oncogenic role of EZH2}

As EZH2 regulates cell cycle progression, dysregulation of EZH2 accelerates cell proliferation, and prolongs cell survival, which might lead to carcinogenesis and cancer development. Ectopic expression of EZH2 in breast epithelial cells could induce anchorage-independent colony growth and promote cell invasion, which is a demonstration of the oncogenic role of EZH2 [20]. EZH2 could inhibit apoptosis by regulation of E2F1-dependent apoptosis through epigenetically modulating Bim expression [21]. Different dysregulations are found in different types of cancers.

EZH2 overexpression was first identified in prostate cancer and associated with poor clinical outcomes [22]. More researches show evidences of EZH2 overexpression in many other cancer types, including breast cancer [23], esophageal cancer [24], gastric cancer [25], anaplastic thyroid carcinoma [26], nasopharyngeal carcinoma [27], and endometrial carcinoma [28]. IHC assessment of 62 samples shows that EZH2 expression is significantly higher in BAP1-mutant renal clear cell carcinoma patients with progressed stage, grade, nodal invasion, and metastasis [29]. Realtime qRT-PCR in 156 gastric cancer cases and immunoblot in randomly selected 20 cases showed that EZH2 was overexpressed in gastric cancer tissues compared with the matched adjacent normal mucous, and EZH2 overexpression is positively correlated with the tumor size, lymphatic invasion and TNM stage, and poor disease-free survival and overall survival of patients [25].

Different from the above solid tumor types, somatic mutations of EZH2 are identified in hematologic malignancies [30]. In B cell lymphoma, heterozygous point mutation occurred at the tyrosine 641 within the $\mathrm{C}$ terminal catalytic SET domain of EZH2 [31]. This mutation mediates the gain-of-function of $\mathrm{EZH} 2$ enzymatic activity, therefore, promotes $\mathrm{H} 3 \mathrm{~K} 27 \mathrm{me} 3$ and suppress gene expressions more strongly in lymphoma [32]. A meta-analysis of 8 studies including 2243 patients that evaluates the correlation between EZH2 mutations and overall survival in patients with myeloid neoplasms shows that EZH2 mutations were associated with significantly worse overall survival (hazard ratio $=2.37,95 \%$ confidential interval, 1.48-3.79) [33].

\section{Role of EZH2 in cancer cells metastasis}

A knockdown of EZH2 experiment indicates its potential role in metastasis. Human lung cancer cell linesA549 and A129L cells were transfected with shRNA, migration ability was determined by wound healing assay and invasion ability was determined by transwell assay, and the results showed that knockdown of EZH2 markedly decreased migration and invasion ability of A549 and A129L cells. Besides, matrix-metalloproteinases (MMPs), which were closely related to the cancer cells invasion and metastasis, were downregulated by $\mathrm{EZH} 2$ knockdown [34].

An in vivo experiment proves the important role of $\mathrm{EZH} 2$ in cancer cells metastasis. In control melanoma model mice, melanoma-positive lymph nodes and distant metastasis in the lung are consistently developed; while in EZH2 conditional knockout mice, there is a significant reduction of lymph node metastasis and a virtual absence of lung metastasis [35].

Epithelial-mesenchymal transition (EMT) is the necessary and initial process of cell invasion and metastasis. In a pancreatic cancer cells experiment, exogenous overexpression of EZH2 resulted in increased expression of the mesenchymal marker Vimentin and decreased epithelial marker E-cadherin level, while EZH2 knockdown resulted in decreased expression of Vimentin and increased expression of E-cadherin [36]. These results reflected that EZH2 could promote EMT in pancreatic cancer cells.

Tumor angiogenesis plays an important role in tumor metastasis, EZH2 is also a key regulator of this process. The increase in endothelial EZH2 is a direct result of VEGF stimulation by a paracrine circuit that promotes angiogenesis by methylating and silencing vasohibin 1 [37].

\section{Tumor suppressive roles of EZH2}

While many researches have revealed oncogenic roles of $\mathrm{EZH} 2$, the tumor-suppressive roles are also reported. Cerulein could induce pancreatic injury. Histological changes include disordered acinar structure and abundant presence of metaplastic lesions. EZH2 is upregulated in the injured pancreatic tissue. Increased expression of EZH2 represses the CDK inhibitor $p 16^{\text {Ink } 4 a}$, therefore, controls the proliferative potential of PDX1-positive progenitor cells that accumulate transiently in metaplastic lesions, which is required during pancreatic repair. While loss of EZH2 blocks progenitor cells proliferation and redifferentiation into acini, thereby bringing regeneration to a halt and resulting in chronic injury. As chronic pancreatic injury is associated 
with high neoplastic risk, loss of EZH2 promotes neoplastic progression, which is also demonstrated by the mice experiment that loss of EHZ2 accelerates $\mathrm{KRas}^{\mathrm{G12D}}$-driven neoplasia [38]. T cell acute lymphoblastic leukemia (T-ALL) is an immature hematopoietic malignancy driven mainly by oncogenic activation of NOTCH1 signaling, which induces loss of the repressive mark H3K27me3 by antagonizing the activity of PRC2 [39]. In Kras-driven lung adenocarcinoma, deletion and mutations of EZH2 are frequently present, and loss-offunction alterations are observed, which demonstrated that EZH2 might act as a tumor suppressor. Mechanistically, EZH2 loss amplified Akt and ERK activation through de-repressing its target insulin-like growth factor 1 [40]. An in vivo study shows that EZH2 concurrent knockout in mice with JAK2-V617F transgene resulted in a synergistic effect - very high platelet and neutrophil counts, more advanced myelofibrosis, and reduced survival. Moreover, JAK2-V617F-expressing mice treated with an EZH2 inhibitor showed higher platelet counts, mimicking the genetic knockout. These observations indicate that loss of EZH2 in hematopoietic cells might contribute to the development of myeloproliferative neoplasm; therefore, EZH2 might play a tumor-suppressive role [41].

\section{Role of EZH2 in cancer immunity}

In the immune microenvironment of cancer cells, there are many kinds of immune cells and cytokines that interact with cancer cells to form a complex regulatory network. EZH2 expression in both cancer cells and immune cells have effects on cancer immunity.

EZH2 expression in cancer cells could suppress cancer immunity. EZH2 expression in ovarian tumor represses the tumor production of Th1-type chemokines CXCL9 [42], which plays a key role in CD8+ T cell infiltration in tumors [43]. The levels of EZH2 in ovarian tumor negatively correlated with intratumoral $\mathrm{CD}^{+} \mathrm{T}$ cells [42]. Tumor-associated macrophages (TAMs) acquired M2 phenotype could produce cytokines, including IL-6, IL10 , and $\mathrm{C}-\mathrm{C}$ motif chemokine ligand 20 (CCL20), to reduce anti-tumor immune response and support tumor growth. EZH2 inhibition by siEZH2 in glioblastoma multiforme (GBM) cells could decrease the expression of M2 markers (TGF $\beta 1-2$, STAB1, Ym1, Lyvel, Fizz1, CD206, CD163) and increases the expression of M1 markers (TNF $\alpha$ and iNOS) in co-culturing microglia, which indicated that EZH2 in GBM cells promotes microglia shifting toward M2 phenotype. Moreover, EZH2 inhibition in GBM cells accelerated phagocytic capacities of TAMs. The mechanism is that as iNOS is increased, the production of $\mathrm{NO}$ is also increased, which plays an important role in the microglia phagocytic capacity under inflammatory conditions [44].
EZH2 expression in effector T cells and dendritic cells (DCs) could promote anti-cancer immunity. EZH2 expression in naïve $\mathrm{T}$ cells promotes survival, proliferation, and function of effector T cells [45]. EZH2 plays a key role for the function of tumor-specific effector $\mathrm{T}$ cells, while tumor microenvironments reduce EZH2 expression of $\mathrm{T}$ cells via glucose restriction and in turn, mediates $\mathrm{T}$ cell dysfunction [46]. The main function of DCs is antigen presentation and activation of primary $\mathrm{T}$ cells. EZH2 is necessary in the activation of DCs in allergic rhinitis and mediates epigenetic modification in allergen immunotherapy [47]. However, the effect of EZH2 on DCs in tumor microenvironment still needs further investigation.

Meanwhile, EZH2 expression in regulatory $\mathrm{T}$ cells (Tregs), helper $\mathrm{T}$ (Th) cells, and natural killer (NK) cells could suppress anti-cancer immunity. Tregs are critical for maintaining immune homeostasis as it suppresses immunity, but their presence in tumor tissues impairs anti-tumor immunity, thereby promoting tumor development and metastasis. Disruption of EZH2 activity in Tregs, either pharmacologically or genetically, drove the acquisition of pro-inflammatory functions in tumorinfiltrating Tregs, remodeling the tumor microenvironment and enhancing the recruitment and function of CD8+ and CD4+ effector $\mathrm{T}$ cells that eliminate tumors [48]. Th cells are important in the process of immune response and it could differentiate into many types of Th cells that play different roles. Inactivation of EZH2 could enhance Th1 and Th2 cell differentiation and plasticity [49]. NK cells participate in innate immune response, which can recognize and perform cytotoxicity against cancer cells. In the tumor microenvironment, NK cells differentiation and functions are repressed. Selective loss of EZH2 or inhibition of its enzymatic activity with small molecules in NK cells not only enhances NK cells commitment but also improves mature NK cells function, associated with upregulation of CD122 and the C-type lectin receptor NKG2D [50].

\section{Role of EZH2 in metabolism}

Even when oxygen supply is enough, cancer cells obtain oxygen mainly from glycolysis, which is called the Warburg effect. In a prostate cancer study, the depletion of EZH2 inhibited prostate cancer cell growth and aerobic glycolysis accompanying the upregulation of miR-181b. EZH2 regulated aerobic glycolysis through miR-181b/ hexokinase 2 (HK2) axis and played a positive role in cancer development [51].

EZH2 regulates adipocyte lipid metabolism. EZH2 inhibition promotes lipoprotein-dependent lipid accumulation via inducing ApoE expression in adipocytes [52]. In glioblastoma, siRNA-mediated EZH2 knockdown resulted in fatty acid synthase decrease, accompanied by 
diminished fatty acid levels. EZH2 regulates lipid metabolism through EZH2-TERT-lipid metabolism network [53].

\section{Role of EZH2 in drug resistance}

Many cancer patients eventually generate resistance after treatment with chemotherapy drugs. Platinum drugs are used in first line to treat ovarian cancer, and most patients show high response to platinum drugs treatment initially, but nearly $80 \%$ of them develop recurrent tumors within 2 years and eventually generate acquired resistance against platinum drugs. Recent study revealed that EZH2 regulated cisplatin resistance in ovarian cancer through c-Myc-miR137-EZH2 axis. Cisplatin treatment could induce production of ROS and generate cytotoxicity. Increased ROS production promoted expression of c-Myc, which activates expression of EZH2 by suppressing miR-137. High expression level of EZH2 could activate cell survival pathways, thereby promoting cisplatin resistance [54].

EZH2 is also associated with target drug resistance. Gefitinib is a tyrosine kinase inhibitor of epidermal growth factor receptor (EGFR), which is used to treat advanced EGFR mutated non-small-cell lung cancer (NSCLC). Recruited by long intergenic non-coding RNA 00665, EZH2 activated PI3K/AKT pathway and induced acquired resistance to gefitinib in NSCLC [55]. Tamoxifen, an antiestrogen drug, is used for the treatment of estrogen receptor (ER) positive breast cancer patients. EZH2 regulated tamoxifen resistance in breast cancer by the EZH2-ER $\alpha$-GREB1 transcriptional axis [56].

\section{Targeting EZH2 drugs and strategy}

As EZH2 plays important roles in the pathophysiology of cancer, it becomes a potential target for cancer therapy. Different types of EZH2 inhibitors have been developed, and there are a number of ongoing clinical trials of drugs targeting EZH2 in different cancer types (Table 1). The details can be inquired on the database of ClinicalTrials [57]. The classification and mechanisms of EZH2 inhibitors are shown in Table 2.

\section{Inhibitors of EZH2 methyltransferase activity}

The first EZH2 inhibitor was 3-deazaneplanocin A (DZNep). DZNep, a known S-adenosyl-L-homocysteine (SAH) hydrolase inhibitor, indirectly inhibits EZH2 through the increase of SAH, which directly represses Sadenosyl-L-methionine-dependent histone methyltransferase activity. Thus, DZNep globally inhibits histone methylation and is not specific to EZH2 [58].

Since 2012, several potent and highly selective Sadenosyl-methionine-competitive inhibitors of EZH2 methyltransferase activity have been developed. Most of them have a common structural feature, a 2-pyridone core. The pyridone can occupy partially the site for the co-substrate S-adenosyl-methionine (SAM) in the binding pocket of EZH2 while SAM is the methyl donor [59].

GSK126 (GSK2816126) can inhibit wild type and Y641 mutant EZH2 with similar potency and is highly selective compared to EZH1 (150-fold increased potency) or 20 other methyltransferases ( $>$ 1000-fold selective for EZH2) [60]. A multicenter phase 1 clinical trial to evaluate the safety, maximum-tolerated dose (MTD), pharmacokinetics, and pharmacodynamics of GSK126 (NCT02082977) in patients with advanced hematologic and solid tumors was terminated. Forty-one participants (21 solid tumors, 20 lymphoma) received escalating doses of GSK2816126 ranged from 50 to $3000 \mathrm{mg}$ twice weekly as an intravenous solution for 28 days ( 3 weeks on/1 week off) in the study. The results showed insufficient evidence of clinical activity, and did not justify further clinical investigation while the dosing method and relatively short half-life limited effective exposure [61]. In an experiment administering GSK126 treatment on tumor model mice, the results turned out that GSK126 had no effect on tumors in immunocompetent hosts, unlike that observed in immunodeficient hosts. The difference in the presence of myeloid-derived suppressor cells (MDSCs) between these two kinds of hosts might be the reason. MDSCs play an immunosuppressive role in the tumor microenvironment as it produces IL-6 and NO. GSK126 could promote hematopoietic progenitor cells differentiation to MDSCs, leading to increased MDSCs and immunosuppression, which might offset its antitumor effect on immunecompetent hosts. Neutralizing antibodies against the myeloid differentiation antigen GR-1 or gemcitabine/5-fluorouracil can deplete MDSCs; thus, they can enhance the activity of GSK126 [62]. EPZ005687 [63], an EZH2 inhibitor concurrently developed with GSK126, with high affinity and selectivity for EZH2, has substandard pharmacokinetic properties that limit its clinical application. EI1 [64], another highly selective SAM-competitive inhibitor of EZH2, can inhibit the growth of DLBCL cells carrying Y641 mutations.

Later on, several other SAM-competitive inhibitors of EZH2 were developed including GSK343 [65], GSK926 [65], and tazemetostat (E7438/EPZ6438) [66]. GSK926 and GSK343 can suppress histone H3K27me3 level and inhibit EZH2 activity in breast and prostate cancer cells, while GSK343 can only be used in vitro due to the high clearance in rat PK studies [65]. Tazemetostat has improved potency and pharmacokinetic properties compared to EPZ005687 and can be taken orally in animals [67]. This compound is under evaluation in a series of clinical trials (Table 1 ). In a phase 2 , multicenter, openlabel, single arm, 2-stage study of tazemetostat $800 \mathrm{mg}$ BID administered orally in continuous 28 daycycles (NCT02601950), patients were enrolled into seven cohorts based on tumor type after screening through 21 
Table 1 Clinical studies of drugs targeting EZH2

\begin{tabular}{|c|c|c|c|c|c|c|}
\hline NCT Number & Title & status & Conditions & Drug & Phases & Refs \\
\hline \multicolumn{7}{|c|}{ Tazemetostat (an EZH2 inhibitor) } \\
\hline NCT04224493 & $\begin{array}{l}\text { Study in Subjects With Rela psed/Refractory Follicular } \\
\text { Lymphoma }\end{array}$ & $\begin{array}{l}\text { Not yet } \\
\text { recruiting }\end{array}$ & Relapsed/Refra ctory Follicular Lymphoma & $\begin{array}{l}\text { Tazemetostat/ } \\
\text { Placebo oral } \\
\text { tablet/lenalidomide/ } \\
\text { Rituximab }\end{array}$ & Phase 3 & \\
\hline NCT02220842 & $\begin{array}{l}\text { A Safety and Pharmacology Study of Atezolizumab } \\
\text { (MPDLL23280A) Administered With Obinutuzumab or } \\
\text { Tazemetostat in Particicants With Relapsed/Refra ctory } \\
\text { Follicicular Lymphoma and Diffuse Large B-cell Lymphoma }\end{array}$ & Completed & Lymphoma & $\begin{array}{l}\text { Atezolizumab/ } \\
\text { Obinutuzumab/ } \\
\text { Tazemetostat }\end{array}$ & Phase 1 & \\
\hline NCT03854474 & $\begin{array}{l}\text { Tazemetostat and Pembrolizumab in Treating Patients With } \\
\text { Locally Advanced or Metastatic Urothelial Carcinoma }\end{array}$ & Recruiting & $\begin{array}{l}\text { Advanced Urothelial Carcinoma/Locally Advanced Urothelial } \\
\text { Carcinoma/Metastatic Bladder Urothelial Carcinoma/Metastatic } \\
\text { Urothelial Carcinoma/Stage IIIA-IVB Bl adder Cancer ACCC v8 }\end{array}$ & $\begin{array}{c}\text { Pembrolizumab } \\
\text { /Tazemetostat }\end{array}$ & Phase $1 / 2$ & \\
\hline NCTO4241835 & $\begin{array}{l}\text { A Study of Oral Tazemetostat in Subjects With Moderate and } \\
\text { Severe Hepatic Impairment With Advanced Malignancies }\end{array}$ & Recruiting & Hepatic Impairment/Advanced Malignant Solid Tumor & Tazemetostat & Phase 1 & \\
\hline NCT03456726 & $\begin{array}{c}\text { Study of Tazemetostat in Participants With Relapsed or } \\
\text { Refractory B-cell Non-Hodgkin's Lymphoma With EZH2 Gene } \\
\text { Mutation }\end{array}$ & $\begin{array}{l}\text { Active, not } \\
\text { recruiting }\end{array}$ & Relapsed or Refra ctory B-cell Non-Hodgkin's Lymphoma & Tazemetostat & Phase 2 & \\
\hline NCT03348631 & $\begin{array}{l}\text { Tazemetostat in Treating Patients With Recurrent Ovarian or } \\
\text { Endometrial Concer }\end{array}$ & Suspended & $\begin{array}{l}\text { FIGO Grade } 1 / 2 \text { Endometrial Endometrioid } \\
\text { Adenocarcinoma/Endometri idid Adenocarcinoma/Recurrent } \\
\text { Ovarian Carcinoma/Recurrent Ovarian Clear Cell } \\
\text { Adenocarcinoma/Recurrent Ovarian Endometrioid }\end{array}$ & Tazemetostat & Phase 2 & \\
\hline NCT03213665 & $\begin{array}{l}\text { Tazemetostat in Treating Patients With Rela psed or } \\
\text { Refractory Advanced Solid Tumors, Non-Hodgkin Lymphoma, } \\
\text { or Histiocytic Disorders With ERH2, SMARCB1, or SMARCA4 } \\
\text { Gene Mutations (A Pediatric MATCH Treatment Trial) }\end{array}$ & Recruiting & $\begin{array}{l}\text { Adenocarcinoma/Recurrent Uterine Corpus Carcinoma } \\
\text { solid tumors, non-hodgkin lymphoma, or histiocytic disorders that } \\
\text { have spread to other places in the body and have come back or do } \\
\text { not respond to treatment and have EzH2, SMARCB1, or SMARCA4 } \\
\text { gene mutations }\end{array}$ & Tazemetostat & Phase 2 & \\
\hline NCTO3009344 & $\begin{array}{l}\text { A Phase } 1 \text { study of Tazemetostat in Patients With Relapsed or } \\
\text { Refractory B-cell Non-Hodgkin's Lymphoma }\end{array}$ & $\begin{array}{l}\text { Active, not } \\
\text { recruiting }\end{array}$ & Relapsed or Refractory B-cell Non-Hodgkin's Lymphoma & tazemetostat & Phase 1 & \\
\hline NCT02875548 & $\begin{array}{l}\text { Tazemetostat Rollover Study (TRusT): An Open-Label Rollover } \\
\text { Study }\end{array}$ & Recruiting & $\begin{array}{c}\text { Diffuse Large B-cell Lymphoma/Follicular Lymohoma/Malignant } \\
\text { Rhabdoid Tumors (MRT)//Rhabdioid Tumors of the Kidney } \\
\text { (RTK//Atypical Teratoid Rhabdoid Tumors (ATRT//Synovial } \\
\text { Sarcoma/Epitheliod Sarcoma/Mesothelioma/Advanced Solid } \\
\text { Tumors }\end{array}$ & Tazemetostat & Phase 2 & \\
\hline NCT02860286 & $\begin{array}{l}\text { Study of the EZH2 Inhibitor Tazemetostat in Malignant } \\
\text { Mesothelioma }\end{array}$ & Completed & Mesothelioma/BAP1 Loss of function & Tazemetostat & Phase 2 & \\
\hline NCT02601950 & $\begin{array}{l}\text { A Phase ll, Multicenter Study of the EZH2 Inhibitor } \\
\text { Tazemetostat in Adult Subjects With INI1-Negative Tumors or } \\
\text { Rel apsed/Refractory Synovial Sarcoma }\end{array}$ & Recruiting & 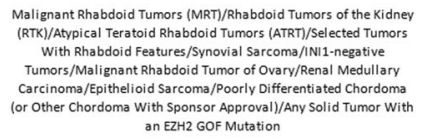 & Tazemetostat & Phase 2 & \\
\hline NCT02601 & $\begin{array}{l}\text { A Phase } 1 \text { Study of the EZH2 Inhibitor Tazemetostat in } \\
\text { Pediatric Subjects With Relapsed or Refractory IN11-Negative } \\
\text { Tumors or Synovial Sarcoma }\end{array}$ & Recruiting & $\begin{array}{l}\text { Rhabdoid Tumors/IN11-negative Tumors/Synovial } \\
\text { Sarcoma/Malignant Rhabdoid Tumor of Ovary }\end{array}$ & Tazemetostat & Phase 1 & \\
\hline NCTO1897571 & 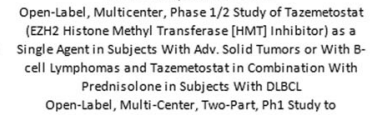 & $\begin{array}{l}\text { Active, not } \\
\text { recruiting }\end{array}$ & $\begin{array}{l}\text { B-cell Lymphomas (Phase 1)/Advanced Solid Tumors (Phase } \\
\text { 1)/Diffuse Large B-cell Lymphoma (Phase 2)/Foll licular Lymphoma } \\
\text { (Phase 2)/Transformed Follicular Lymphoma/Primary Mediastinal } \\
\text { Large B-Cell Lymphoma }\end{array}$ & Tazemetostat & Phase $1 / 2$ & \\
\hline NCT03010982 & $\begin{array}{l}\text { Characterize the PKs of an Intravenous Micro-Dose of [14C]- } \\
\text { Tazemetestat (ERP 6438) and the ADME of an Oral [14C]- } \\
\text { Labeled Dose of Tazemetostat in Subjects With B-Cell } \\
\text { Lymphomas or Adv Solid Tumors }\end{array}$ & Completed & $\begin{array}{l}\text { Diffuse Large B Cell Lymphoma/Primary Mediastinal } \\
\text { Lymphoma/Mantle-Cell Lymphoma/Follicular Lymphoma/Marginal } \\
\text { Zone Lymphoma/Advanced Solid Tumors }\end{array}$ & $\begin{array}{l}\text { Tazemetos tat and } \\
\text { [14C] Tazemetostat }\end{array}$ & Phase 1 & 57] \\
\hline NCT04179864 & $\begin{array}{l}\text { A Phase } 1 \mathrm{~b} / 2 \text { Open-Label Study in Chemotherapy Naive } \\
\text { Subjects With Metastatic Castration-Resistant Prostate } \\
\text { Cancer }\end{array}$ & Recruiting & Metas tatic Prostate Cancer & $\begin{array}{l}\text { Tazemetostat/Abira- } \\
\text { terone/prednisone/ } \\
\text { Enzalutamide }\end{array}$ & Phase 1 & \\
\hline NCTO3028103 & $\begin{array}{l}\text { Open-Label, Multicenter, Two-Part, Phase } 1 \text { Study to } \\
\text { Characterize Effects of a Moderate CYP3A Inhibitor yn PK of } \\
\text { Tazemetostat, Effects of Tazemetostat on PK of CYP2C8 and } \\
\text { CYP2C19 Substrates, and Effect of Increased Gastric P O O PK } \\
\text { of Tazemetostat in B-cell Lymphoma or Advanced Solid Tumor } \\
\text { Patients }\end{array}$ & $\begin{array}{l}\text { Active, not } \\
\text { recruiting }\end{array}$ & $\begin{array}{c}\text { Diffuse Large B Cell Lymphoma/Primary Mediastinal } \\
\text { Lymphoma/Mantle Cell Lymphoma/Advanced Solid } \\
\text { Tumor/Marginal Zone Lymphoma }\end{array}$ & $\begin{array}{l}\text { Tazemetostat/Fluc- } \\
\text { onazole/Omeprazole/ } \\
\text { Repaglinide }\end{array}$ & Phase 1 & \\
\hline NCT04204941 & $\begin{array}{l}\text { Tazemetostat in Combination With Doxorubicin as Frontline } \\
\text { Thera py for Advanced Epithelioid Sarcoma }\end{array}$ & Recruiting & Advanced Soft Tissue Sarcoma/Advanced Epithelioid Sarcoma & $\begin{array}{l}\text { Tazemetostat/Plac- } \\
\text { ebo/Doxorubicin HCl } \\
\text { Tazemetostat/ }\end{array}$ & Phase 3 & \\
\hline NCTO2889523 & $\begin{array}{l}\text { Study of Tazemetostat in Newly Diagnosed Diffuse Large B } \\
\text { Cell Lymphoma Patients Treated by Chemiotherapy }\end{array}$ & Suspended & Lymphoma, Large B-Cell, Diffuse & $\begin{array}{l}\text { Rituximab/ cycloph- } \\
\text { osphamide/ Vincr- } \\
\text { istine/Doxorubicin/ } \\
\text { Prednisolone }\end{array}$ & Phase $1 / 2$ & \\
\hline \multicolumn{7}{|c|}{ CPI-1205 (an EZH2 inhibitor) } \\
\hline NCT02395601 & $\begin{array}{l}\text { A Study Evaluating CPl-1205 in Patients With B-cell } \\
\text { Lymphomas }\end{array}$ & completed & B-Cell Lymphoma & CPI-1205 & Phase 1 & \\
\hline NCT03480646 & $\begin{array}{l}\text { ProSTAR: A Study Evaluating CPl-1205 in Patients With } \\
\text { Metastatic Castration Resistant Prostate Cancer }\end{array}$ & Recruiting & Metastatic Castration Resistant Prostate Cancer (MCRPC) & $\begin{array}{l}\text { CPl-1205/ } \\
\text { Enzalutamide/ } \\
\text { Abiraterone/ } \\
\text { Prednisone }\end{array}$ & Phase 1/2 & \\
\hline NCT03525795 & $\begin{array}{l}\text { ORIOn-E: A Study Evaluating CPI-1205 in Patients With } \\
\text { Advanced Solid Tumors }\end{array}$ & $\begin{array}{l}\text { Active, not } \\
\text { recruiting }\end{array}$ & Advanced Solid Tumors & CPI-1205/ipilimumab & Phase $1 / 2$ & \\
\hline NCTO4104776 & A Study of CP1-0209 in Patients With Advanced Solid Tumors & Recruiting & Advanced Solid Tumor & CPI-0209//rinotecan & Phase $1 / 2$ & \\
\hline \multicolumn{7}{|c|}{ other EZH2 inhibitors } \\
\hline NCT02082977 & $\begin{array}{l}\text { A Study to Investigate the Safety, Pharmacokinetics, } \\
\text { Pharmacodynamics and Clinical Activity of GSK2816126 in } \\
\text { Subjects With Relapsed/Refractory Diffuse Large B Cell } \\
\text { Lymphoma, Transformed Follicular Lymphoma, other Non- } \\
\text { Hodgkin's Lymphomas, Solid Tumors and Multiple Myeloma }\end{array}$ & Terminated & Cancer/Neoplasms & GSK2816126 & Phase 1 & \\
\hline NCT03460977 & $\begin{array}{l}\text { PF-o6821497 Treatment Of felapsed/Refiractory SSLC, } \\
\text { Castration Resistant Prostate Cancer, and Follicular } \\
\text { Lymphoma }\end{array}$ & Recruiting & $\begin{array}{l}\text { Small Cell Lung Cancer (SCLC)/Follicular Lymphoma (FL)/Castration } \\
\text { Resistant Prostate Cancer (CFPC)/Diffuse Large B-Cell Lymphoma } \\
\text { (DLBCL) }\end{array}$ & PF-06821497 & Phase 1 & \\
\hline NCT03603951 & $\begin{array}{l}\text { A Phase } 1 \text { Study of SHR2554 in Subjects With Relapsed or } \\
\text { Refractory Mature Lymphoid Neoplasms }\end{array}$ & Recruiting & Relapsed or Refractory Mature Lymphoid Neoplasms & SHR2554 & Phase 1 & \\
\hline NCT03741712 & $\begin{array}{l}\text { A Study of SHR2554 Alone or in Combination With SHR3680 } \\
\text { in the Treatment of mCRPC }\end{array}$ & Recruiting & Prostate Cancer/Castration-resistant Prostate Cancer & SHR3680/SHR2554 & Phase $1 / 2$ & \\
\hline \multicolumn{7}{|c|}{ EZH1/2 inhibitors } \\
\hline NCT04276662 & $\begin{array}{l}\text { Study of Single-dose DS-3201b in Participants With Hepatic } \\
\text { Impairment }\end{array}$ & Recruiting & Hepatic Impairment & DS-3201b & Phase 1 & \\
\hline NCT04102150 & $\begin{array}{l}\text { Valemetostat Tosvlate (DS-32016) Phase } 2 \text { Study in Relapsed } \\
\text { or Refractory Adult T-cell Leukemia/Lymphoma }\end{array}$ & Recruiting & Adult T-cell Leukemia/Lymphoma & DS-3201b & Phase 2 & \\
\hline NCT03110354 & $\begin{array}{l}\text { DS-3201b for Acute Myelogenous Leukemia (AML) or Acute } \\
\text { Lymphocytic Leukemia (ALL) }\end{array}$ & Recruiting & Leukemia, Myel oid, Acute/Leukemia, Lymphocytic, Acute & DS-3201b & Phase 1 & \\
\hline NCT03879798 & DS-3201b and Irinotecan for Patients With Recurrent Small & Recruiting & Small Cell Lung Cancer & DS-3201b/irinotecan & Phase $1 / 2$ & \\
\hline NCTO2732275 & $\begin{array}{l}\text { Cell Lung Cancer } \\
\text { DS-3201b in Participants With Lymphomas }\end{array}$ & Recruiting & Lymphoma, Malignant/Non-hodgkin Lymphoma & DS-3201b & Phase 1 & \\
\hline \multicolumn{7}{|c|}{ An EED inhibitor } \\
\hline NCT02900651 & $\begin{array}{l}\text { Safety and Efficacy of MAK683 in Adult Patients With } \\
\text { Advanced Malignancies }\end{array}$ & Recruiting & Diffuse Large B-cell Lymphoma & MAK683 & Phase $1 / 2$ & \\
\hline
\end{tabular}


Table 2 EZH2 inhibitors and their mechanisms of action

\begin{tabular}{|c|c|c|c|}
\hline \multirow{3}{*}{$\begin{array}{l}\text { Inhibitors of EZH2 } \\
\text { methyltransferase } \\
\text { activity }\end{array}$} & \multicolumn{2}{|c|}{$\begin{array}{l}\text { SAH hydrolase inhibitor which globally inhibits } \\
\text { histone methylation }\end{array}$} & \multirow{2}{*}{$\begin{array}{c}\text { 3- deazaneplanocin A (DZNep) } \\
\text { GSK126(GSK2816126),EPZ005687,EI1,GSK343,GSK926,tazemetostat } \\
\text { (E7438/EPZ6438),EPZ011989,CPI-1205,CPI-169,ZLD1039, PF-06821497 }\end{array}$} \\
\hline & \multirow{2}{*}{$\begin{array}{l}\text { SAM-competitive } \\
\text { inhibitors }\end{array}$} & EZH2 Inhibitors & \\
\hline & & EZH1/2 Inhibitors & UNC1999,OR-S1/OR-S2,DS-3201b \\
\hline \multirow{2}{*}{$\begin{array}{l}\text { Inhibitors that } \\
\text { break PRC2's } \\
\text { structure }\end{array}$} & \multicolumn{2}{|c|}{ disrupting the EZH2-EED interaction } & $\begin{array}{l}\text { SAH-EZH2,Astemizole, Wedelolactone, apomorphine hydrochloride, } \\
\text { oxyphenbutazone, nifedipine,ergonovine } \\
\text { maleate,AZD9291,MAK683(EED226) }\end{array}$ \\
\hline & \multicolumn{2}{|c|}{ disrupting the EZH2-SUZ12 interaction } & A769662(an AMPK agonist) \\
\hline $\begin{array}{l}\text { Suppressing EZH2 } \\
\text { through triggering } \\
\text { EZH2 degradation }\end{array}$ & \multicolumn{3}{|c|}{ GNA022, ANCR ,FBW7,ZRANB1 siRNA and other inhibitors } \\
\hline
\end{tabular}

days of the first planned dose of tazemetostat [68]. In cohort 5, there were 62 patients (59 adults and 3 pediatric $\geq 16$ years) with a documented diagnosis of metastatic or unresectable, locally advanced epithelioid sarcoma (ES). The objective response rate (ORR) for patients with ES was $15 \%$, and the median duration of response (DOR) was 16 months. Sixty-eight percent of patients had a reduction in tumor burden. Median overall survival (mOS) was 19 months [69]. As for the clinical safety, tazemetostat shows a favorable safety and tolerability profile while most adverse events (AEs) are mild to moderate and resolved without the need for discontinuation or dose reductions [70]. Inspiringly, on January 23, 2020, tazemetostat (TAZVERIK, Epizyme, Inc.) was approved by FDA for adults and pediatric patients aged 16 years and older with metastatic or locally advanced epithelioid sarcoma not eligible for complete resection. Now, a phase 2, open-label, multi-center clinical trial for relapsed/refractory follicular lymphoma (FL) is ongoing [71]. As of the cutoff date, after screening and archival tissue analysis for EZH2 hot spot activating mutations, patients were enrolled into two cohorts (FL, EZH2 MT (cohort $1, n=45$ ) and FL, EZH2 WT (cohort 2, $n=$ 54)). Patients were treated with tazemetostat $800 \mathrm{mg}$ BID until progressive disease or withdrawal, and responses were assessed every 8 weeks. Treatment with tazemetostat was generally well tolerated and no treatment-related deaths were observed. The ORR for patients in cohort 1 was $77 \%$ and ORR in cohort 2 was 34\%. Median DOR was 8.3 months in cohort 1 and 13 months in cohort 2. Median PFS was 11.1 months in cohort 1 and 5.7 months in cohort 2 (median DOR and PFS were not mature for the MT cohort). The results showed tazemetostat is a promising therapeutic drug for patients with relapsed/refractory follicular lymphoma.

EPZ011989 [72], another selective and orally bioavailable EZH2 inhibitor reported in 2015, was able to inhibit tumor growth significantly in a mouse xenograft model of human B cell lymphoma. Then, CPI-1205 [73], an orally bioavailable, indole-based, small-molecule inhibitor of EZH2 optimized from CPI-169 [74] was reported. CPI-169, a previously disclosed indole based EZH2 inhibitor, shows significant antitumor activity and pharmacodynamic (PD) target engagement in a mouse xenograft model of a KARPAS-422 lymphoma while accompanied by limited oral bioavailability [74]. CPI-1205 was evaluated in a completed phase 1 clinical trial for B cell lymphoma (NCT02395601). Furthermore, CPI-1205 is currently being evaluated in a phase $1 / 2$ clinical trial for advanced solid tumors (NCT03525795) and a phase $1 / 2$ clinical trial for metastatic castration-resistant prostate cancer (NCT03480646). ZLD1039 is a highly selective, and orally bioavailable inhibitor of EZH2, which inhibits breast tumor growth and metastasis in mice [75]. PF-06821497 [76] reported in 2018 is currently under evaluation in a phase 1 clinical trial in patients with relapsed/refractory small cell lung cancer (SCLC), castration-resistant prostate cancer (CRPC), FL and diffuse large B-cell lymphoma (DLBCL) (NCT03460977).

Given the fact that EZH1, a homolog of EZH2 physically presented in a non-canonical PRC2 complex, complements EZH2 in mediating H3K27 methylation and also has histone methyltransferase activity [77], dual EZH1/EZH2 inhibition may have greater antitumor efficacy. UNC1999 is the first oral SAM-competitive inhibitor of wild-type and Y641 mutant EZH2 as well as EZH1 [78]. UNC1999 effectively inhibited the growth of MLLrearranged leukemia in mice instead of GSK126 in a study [79]. A more recent study introduced (R)-OR-S1 and (R)-OR-S2, two orally bioavailable EZH1/2 dual inhibitors produced by Daiichi Sankyo [80]. It was found that (R)-OR-S1 and (R)-OR-S2 suppressed H3K27me3 in HCT116 colorectal cancer cells more highly than ORS0, an EZH2 selective inhibitor. Besides, (R)-OR-S1 and (R)-OR-S2 showed greater antitumor efficacy than ORS0 in DLBCL cells harboring Y641N mutation of EZH2 both in vitro and in vivo. Despite of importance of EZH1 in hematopoietic stem cell maintenance [81], long-term EZH1/2 dual inhibition in vivo does not cause serious lympho-hematopoietic toxicity according to this 
study. Daiichi Sankyo soon put DS-3201b, an EZH1/2 inhibitor, into several clinical trials for patients with leukemia, lymphoma, or small cell lung cancer (NCT04276662, NCT03110354, NCT04102150, NCT02732275, NCT038 79798).

\section{Inhibitors that break PRC2's structure}

In addition to targeting the enzyme catalytic domain of EZH2, disrupting the protein-protein interactions among the PRC2 subunits is a novel strategy to inhibit PRC2dependent functions of EZH2.

Peptides known as stabilized alpha-helix of EZH2 (SAH-EZH2) were reported in 2013. SAH-EZH2, derived from the domain of EZH2 that interacts with EED, can disrupt the EZH2-EED interaction through targeting EED leading to an increased level of H3K27me3, reduced EZH2 protein and growth arrest, and differentiation of MLL-AF9 leukemic cells [82]. Furthermore, SAH-EZH2 impaired viability while GSK126 had no effect in MDA-MB231 (breast cancer) and DU145 (prostate cancer) cell lines which have been reported to be driven by non-enzymatic functions for EZH2 [82].

Then, several other inhibitors of the EZH2-EED interaction of PRC2 were identified. Astemizole, an FDAapproved $\mathrm{H} 1$ histamine receptor antagonist, was reported to arrest the proliferation of PRC2-driven lymphoma cells by disrupting the EZH2-EED complex [83]. Wedelolactone which has a high affinity for EED was screened out in natural compounds [84]. Four other FDA-approved drugs (apomorphine hydrochloride, oxyphenbutazone, nifedipine and ergonovine maleate) were discovered as potential EZH2-EED interaction inhibitors through a high-throughput fluorescence polarization assay [85]. A recent study found that AZD9291 (Osimertinib, TAGRISSO), a EGFR inhibitor approved by FDA for the treatment of patients with metastatic EGFR T790M mutation-positive NSCLC, can break the structure of EZH2-EED [85]. Besides, AZD9291 can also suppress the expression of EZH2 through upregulating miR-34a which can bind to EZH2 mRNA [86].

An EED inhibitor developed by Novartis is being evaluated in a phase $1 / 2$ clinical trial for advanced malignancies including DLBCL, nasopharyngeal carcinoma, gastric cancer, ovarian cancer, prostate cancer, and sarcoma (NCT02900651). This inhibitor, MAK683/ EED226, can make PRC2 allosteric through directly binding to the H3K27me3 pocket of EED [87].

Apart from targeting EZH2-EED interaction, disrupting the interaction between EZH2 and SUZ12 was reported in a study [88]. In this study, they demonstrated that AMP-activated protein kinase (AMPK) can disrupt the EZH2-SUZ12 interaction through directly phosphorylating EZH2 at Thr311 and decrease the level of H3K27me3 in ovarian and breast cancer cells [88].

\section{Suppressing EZH2 through triggering EZH2 degradation} Given the fact that EZH2 plays a PRC2- and methylation-independent role in cancer and many cancers do not respond to EZH2 enzymatic inhibitors, triggering EZH2 degradation may be a novel method to inhibit EZH2.

In addition to the abovementioned SAH-EZH2 reducing EZH2 protein through disrupting the PRC2 complex, post-translational modifications of EZH2 can aslo induce the degradation of EZH2. Wang et al. reported a gambogenic acid (GNA) derivative, GNA022, directly covalently bound to Cys668 within the EZH2-SET domain, decreasing the stability of PRC2 complex as well as $\mathrm{H} 3 \mathrm{~K} 27$ trimethylation, triggering EZH2 degradation through $\mathrm{COOH}$ terminus of Hsp70-interacting protein (CHIP)-mediated ubiquitination [89]. Another group found that long non-coding RNA (lncRNA) ANCR can facilitate the CDK1-EZH2 interaction, then phosphorylate EZH2 at Thr345 and Thr487, hence, result in EZH2 ubiquitination and its degradation in breast cancer cells in vitro, and ANCR represses tumor growth and distant metastasis in mice in breast cancer [90]. F-box and WD repeat domain-containing 7 (FBW7), a novel E3 ligase of EZH2, can mediate the phosphorylation, ubiquitination, and degradation of EZH2 with the involvement of the activated CDK5 kinase in pancreatic cancer [91].

$\mathrm{Lu}$ et al. revealed a new signaling network of SKP2TRAF6-EZH2/ H3K27me3 and found knockout of SKP2 can upregulate TRAF6-mediated and lysine (K) 63linked ubiquitination of EZH2 for degradation in prostate cancer ( $\mathrm{PCa}$ ) and CRPC cells in vitro and in vivo [92]. In a study in 2018, ZRANB1 was identified as the EZH2 deubiquitinase and stabilizes EZH2 through interacting with EZH2 via its OTU domain in breast cancer cells. Thus, ZRANB1 small interfering RNA (siRNA) and other ZRANB1 inhibitors have anticancer effects in vitro and in vivo [93].

\section{EZH2 inhibitors combined with other therapy methods}

Combining EZH2 inhibitors with other therapy methods such as immune therapy, conventional chemotherapy, and target therapy might improve the treatment efficacy and overcome the limitation of monotherapy.

As mentioned before, the levels of EZH2 negatively correlated with intratumoral $\mathrm{CD} 8+\mathrm{T}$ cells in ovarian cancer, so EZH2 inhibitor could increase effector $\mathrm{T}$ cell tumor infiltration, slowed down tumor progression, and synergistically improved the efficacy of adoptive $\mathrm{T}$ cell therapy [45]. Furthermore, EZH2 inhibition can increase the cytotoxicity of human effector $\mathrm{T}$ cells in vitro and improve the efficacy of anti-CTLA-4 therapy in murine bladder cancer and melanoma as anti-CTLA-4 increases the expression of EZH2 in peripheral T cells [94]. This study provided basis for the treatment of combining 
CPI-1205 with ipilimumab (anti-CTLA-4). In a phase 1/ 2, multi-center, open-label study (NCT03525795), the strategy of CPI-1205 plus ipilimumab is under evaluation in patients with advanced solid tumors. A recent study revealed the inhibition of EZH2 could enhance cancer cell antigen presentation in head and neck squamous cell carcinoma (HNSCC) and avoid anti-PD-1 resistance [95].

Synergy between EZH2 inhibitors and conventional chemotherapy has been demonstrated in a series of preclinical studies. Synergistic effects of tazemetostat with cyclophosphamide, doxorubicin, oncovin, and prednisone were observed in EZH2 mutant DLBCL [96]. In a multicenter, double-blind, placebo-controlled, randomized phase 3 clinical trial (NCT04204941), the combination of tazemetostat with doxorubicin for patients with advanced ES is being evaluated. Part 1 is designed to evaluate the safety of the combination of tazemetostat plus doxorubicin, as well as to establish the MTD and the recommended dose for part 2. Part 2 is planned to compare the effects of tazemetostat plus doxorubicin with doxorubicin plus placebo, when used as first-line treatment in locally advanced unresectable or metastatic ES [97]. Besides, tazemetostat plus R-CHOP combination (rituximab, cyclophosphamide, vincristine, doxorubicin, prednisolone) in patients with newly diagnosed DLBCL with poor prognosis features is under evaluation in a phase $1 / 2$ clinical trial (NCT02889523). Phase 1 is designed to determine the recommended phase 2 dose for tazemetostat in patients treated with R-CHOP 21 . Phase 2 is designed to determine the safety of tazemetostat in patients treated with 8 cycles of R-CHOP 21 and to determine the complete response rate after 8 cycles of Epi-RCHOP (tazemetostat plus RCHOP) 21. Up to present, 17 patients were enrolled and further evaluation in phase 2 is warranted while this therapeutic method showed preliminary efficacy in phase 1 [98].

Several studies demonstrated co-inhibition of both EZH2 and EGFR could show a synergic effect on tumor growth inhibition through inducing autophagy and increasing apoptosis in colon cancer cells [99], gastric cancer cells [100], and lung cancer cells [101]. Besides, this combination therapy can reverse EGFR-tyrosine kinase inhibitor (EGFR-TKIs) resistance in lung cancer [99]. Futhermore, Hirukawa et al. in 2019 found EZH2 inhibitors could enhance the efficacy of anti-HER2 monoclonal antibodies such as trastuzumab through promoting interferon-driven immune responses in trastuzumabresistant breast cancer models of mice [102]. As previously mentioned, phosphorylated EZH2 activates AR and the activation of AR supports CRPC growth, so combination of EZH2 inhibition and AR-targeted therapies may be effective in CRPR [6]. There are two ongoing clinical trials to evaluate the effects of EZH2 inhibitors plus enzalutamide (an AR antagonist) in mCRPR (NCT04179864, NCT03480646).

To overcome the limitation that EZH2 inhibitors can only benefit certain hematological malignancies, Huang et al. in 2018 found BRD4 inhibitors can decrease the resistance of EZH2 inhibitors caused by H3K27ac upregulation and restore the sensitivity of the insensitive cell lines to EZH2 inhibitors [103]. Besides, as EZH2-BRD4 inhibitor combo differentially activates multiple pathways such as MAPK pathway, a triple combination plus MAPK pathway inhibitors may expand the treatment scope of cancers [103]. However, the therapeutic effects of multi-drug combination require further evaluation in clinical trials, and the side effects and patients' tolerance may be a big problem.

\section{Conclusions}

As a novel and potential target for cancer therapy, EZH2 has become a hotspot of research. More and more functions and roles of EZH2 in multiple kinds of cancer have been revealed. Many new drugs targeting EZH2 are under development and evaluation in clinical trials. Most of them are still on the stage of preclinical study or phase $1 / 2$ clinical trials, only tazemetostat was approved for the treatment of ES and preliminarily showed promising effects on FL.

To further develop EZH2 inhibitors with high efficiency, low toxicity, and high selectivity is one of the future directions. Dual EZH1/EZH2 inhibition may have greater antitumor efficacy because EZH1 can compensate when EZH2 is inhibited. So dual EZH1/EZH2 inhibitors targeting their common sequence with high selectivity or combining highly selective EZH1 inhibitors with highly selective EZH2 inhibitors are both worth being explored. Besides, conducting more clinical trials to evaluate and verify the efficacy of EZH2 inhibitors is significant. Screening predictive biomarkers, such as EZH2 mutation or over-expression, to help select patients suitable for EZH2 target therapy is important in personalized, precision therapy. Biomarker-based selection of patients registered in the clinical trial will be a better strategy to improve the efficacy of EZH2 inhibitor and increase the chance of positive results. Given the fact that single drug has limited efficacy, combining EZH2 inhibitors with other treatments is an essential option and future direction, as pre-clinical studies have already shown that EZH2 inhibitors combined with immunotherapy or chemotherapy has a synergistic effect and has entered the stage of clinical trials.

\section{Abbreviations}

AEs: Adverse events; AMPK: AMP-activated protein kinase; AR: Androgen receptor; CCL20: C-C motif chemokine ligand 20; $\mathrm{CHIP}$ : $\mathrm{COOH}$ terminus of Hsp70-interacting protein; CRPC: Castration resistant prostate cancer;

DCs: Dendritic cells; DLBCL: Diffuse large B cell lymphoma; DOR: Duration of response; DZNep: 3-deazaneplanocin A; EGFR: Epidermal growth factor receptor; EGFR-TKIs: EGFR-tyrosine kinase inhibitor; EMT: Epithelial- 
mesenchymal transition; ER: Estrogen receptor; ES: Epithelioid sarcoma; EZH2: Enhancer of zeste homolog 2; FBW7: F-box and WD repeat domaincontaining 7; FL: Follicular lymphoma; GBM: Glioblastoma multiforme; GNA: Gambogenic acid; H3K27me3: Trimethylation of Lys-27 in histone 3; HK2: Hexokinase 2; HNSCC: Head and neck squamous cell carcinoma; IncRNA: Long non-coding RNA; MDSCs: Myeloid-derived suppressor cells; MMPs: Matrix-metalloproteinases; mOS: Median overall survival; MTD: Maximum-tolerated dose; NK: Natural killer; NSCLC: Non-small-cell lung cancer; ORR: Objective response rate; PCa: Prostate cancer; PcGs: Polycomb group genes; PD: Pharmacodynamics; PRC2: Polycomb repressive complex 2; R-CHOP: Rituximab, cyclophosphamide, vincristine, doxorubicin, prednisolone; SAH: S-adenosyl-L-homocysteine; SAH-EZH2: Stabilized alphahelix of EZH2; SAM: S-adenosyl-methionine; SCLC: Small cell lung cancer; siRNA: Small interfering RNA; T-ALL: T cell acute lymphoblastic leukemia; TAMs: Tumor-associated macrophages; Th cells: Helper T cells; Tregs: Regulatory T cells

\section{Acknowledgements}

Not applicable.

\section{Authors' contributions}

All authors were involved in the collection of data and revised and approved the final manuscript. All authors take the responsibility for publishing this paper.

\section{Funding}

None

\section{Availability of data and materials}

Data sharing is not applicable to this article as no datasets were generated or analyzed during the current study.

\section{Ethics approval and consent to participate}

Not applicable.

\section{Consent for publication}

Not applicable.

\section{Competing interests}

The authors declare that they have no competing interests.

\section{Author details}

'Department of Medical Oncology, Fudan University Shanghai Cancer Center, Shanghai 200032, People's Republic of China. ${ }^{2}$ Department of Oncology, Shanghai Medical College, Fudan University, Shanghai 200032, People's Republic of China. ${ }^{3}$ Shanghai Medical College, Fudan University, Shanghai 200032, People's Republic of China

Received: 3 May 2020 Accepted: 13 July 2020

Published online: 28 July 2020

\section{References}

1. Pasini D, Di Croce L. Emerging roles for Polycomb proteins in cancer. Curr Opin Genet Dev. 2016;36:50-8.

2. Simon JA, Lange CA. Roles of the EZH2 histone methyltransferase in cancer epigenetics. Mutat Res. 2008 Dec 1;647(1-2):21-9.

3. Yin X, Yang S, Zhang M, Yue Y. The role and prospect of JMJD3 in stem cells and cancer. Biomed Pharmacother. 2019 Oct;118:109384.

4. He A, Shen X, Ma Q, Cao J, von Gise A, Zhou P, Wang G, Marquez VE, Orkin $\mathrm{SH}, \mathrm{Pu}$ WT. PRC2 directly methylates GATA4 and represses its transcriptional activity. Genes Dev. 2012;26(1):37-42.

5. Kim E, Kim M, Woo DH, Shin Y, Shin J, Chang N, Oh YT, Kim H, Rheey J, Nakano I, Lee C, Joo KM, Rich JN, Nam DH, Lee J. Phosphorylation of EZH2 activates STAT3 signaling via STAT3 methylation and promotes tumorigenicity of glioblastoma stem-like cells. Cancer Cell. 2013 Jun 10; 23(6):839-52.

6. Xu K, Wu ZJ, Groner AC, He HH, Cai C, Lis RT, Wu X, Stack EC, Loda M, Liu T, Xu H, Cato L, Thornton JE, Gregory RI, Morrissey C, Vessella RL, Montironi R, Magi-Galluzzi C, Kantoff PW, Balk SP, Liu XS, Brown M. EZH2 oncogenic activity in castration-resistant prostate cancer cells is Polycombindependent. Science. 2012 Dec 14;338(6113):1465-9.
7. Kim J, Lee Y, Lu X, Song B, Fong KW, Cao Q, Licht JD, Zhao JC, Yu J. Polycomb- and methylation-independent roles of EZH2 as a transcription activator. Cell Rep. 2018;25(10):2808-20.

8. Nutt SL, Keenan C, Chopin M, Allan RS. EZH2 function in immune cell development [published online ahead of print, 2020 Feb 28]. Biol Chem. 2020;/j/bchm.ahead-of-print/hsz-2019-0436/hsz-2019-0436.xml.

9. Yao Y, Hu H, Yang Y, Zhou G, Shang Z, Yang X, Sun K, Zhan S, Yu Z, Li P, Pan G, Sun L, Zhu X, He S. Downregulation of enhancer of zeste homolog 2 $(E Z H 2)$ is essential for the induction of autophagy and apoptosis in colorectal cancer cells. Genes (Basel). 2016 Oct 3;7:10.

10. Ito T, Teo YV, Evans SA, Neretti N, Sedivy JM. Regulation of cellular senescence by Polycomb chromatin modifiers through distinct DNA damage- and histone methylation-dependent pathways. Cell Rep. 2018; 22(13):3480-92.

11. Batool A, Jin C, Liu YX. Role of EZH2 in cell lineage determination and relative signaling pathways. Front Biosci (Landmark Ed). 2019 Mar 1;24:947-60.

12. Cardoso C, Mignon C, Hetet G, Grandchamps B, Fontes M, Colleaux L. The human EZH2 gene: genomic organisation and revised mapping in 7q35 within the critical region for malignant myeloid disorders. Eur J Hum Genet. 2000 Mar;8(3):174-80.

13. Laible G, Wolf A, Dorn R, Reuter G, Nislow C, Lebersorger A, Popkin D, Pillus $L$, Jenuwein T. Mammalian homologues of the Polycomb-group gene enhancer of zeste mediate gene silencing in Drosophila heterochromatin and at S. cerevisiae telomeres. EMBO J. 1997 Jun 2;16(11):3219-32.

14. Wang R, Xin M, Li Y, Zhang P, Zhang M. The functions of histone modification enzymes in cancer. Curr Protein Pept Sci. 2016;17(5):438-45.

15. Cao $R$, Zhang $Y$. The functions of $E(Z) / E Z H 2$-mediated methylation of lysine 27 in histone H3. Curr Opin Genet Dev. 2004;14(2):155-64.

16. Xu J, Wang Z, Lu W, Jiang H, Lu J, Qiu J, Ye G. EZH2 promotes gastric cancer cells proliferation by repressing p21 expression. Pathol Res Pract. 2019 Jun;215(6):152374.

17. Wang X, Wang C, Zhang X, Hua R, Gan L, Huang M, et al. Bmi-1 regulates stem cell-like properties of gastric cancer cells via modulating miRNAs. J Hematol Oncol. 2016;9(1):90.

18. Zhang XW, Sheng YP, Li Q, Qin W, Lu YW, Cheng YF, Liu BY, Zhang FC, Li J, Dimri GP, Guo WJ. BMI1 and Mel-18 oppositely regulate carcinogenesis and progression of gastric cancer. Mol Cancer. 2010;9:40.

19. Ni SJ, Zhao LQ, Wang XF, Wu ZH, Hua RX, Wan $C H$, et al. CBX7 regulates stem cell-like properties of gastric cancer cells via p16 and AKT-NF-kappaBmiR-21 pathways. J Hematol Oncol. 2018;11(1):17.

20. Kleer CG, Cao Q, Varambally S, Shen R, Ota I, Tomlins SA, Ghosh D, Sewalt RG, Otte AP, Hayes DF, Sabel MS, Livant D, Weiss SJ, Rubin MA, Chinnaiyan AM. EZH2 is a marker of aggressive breast cancer and promotes neoplastic transformation of breast epithelial cells. Proc Natl Acad Sci U S A. 2003; 100(20):11606-11

21. Wu ZL, Zheng SS, Li ZM, Qiao YY, Aau MY, Yu Q. Polycomb protein EZH2 regulates $\mathrm{E} 2 \mathrm{~F} 1$-dependent apoptosis through epigenetically modulating Bim expression. Cell Death Differ. 2010 May; 17(5):801-10.

22. Varambally S, Dhanasekaran SM, Zhou M, Barrette TR, Kumar-Sinha C, Sanda MG, Ghosh D, Pienta KJ, Sewalt RG, Otte AP, Rubin MA, Chinnaiyan AM. The polycomb group protein $\mathrm{EZH} 2$ is involved in progression of prostate cancer Nature. 2002:419(6907):624-9.

23. Bachmann IM, Halvorsen OJ, Collett K, Stefansson IM, Straume O, Haukaas $\mathrm{SA}$, Salvesen HB, Otte AP, Akslen LA. EZH2 expression is associated with high proliferation rate and aggressive tumor subgroups in cutaneous melanoma and cancers of the endometrium, prostate, and breast. J Clin Oncol. 2006 Jan 10;24(2):268-73.

24. Qiu BQ, Lin XH, Ye XD, et al. Long non-coding RNA PSMA3-AS1 promotes malignant phenotypes of esophageal cancer by modulating the miR-101/ EZH2 axis as a ceRNA. Aging (Albany NY). 2020;12(2):1843-56.

25. Gan L, Xu M, Hua R, Tan C, Zhang J, Gong Y, Wu Z, Weng W, Sheng W, Guo $W$. The polycomb group protein EZH2 induces epithelial-mesenchymal transition and pluripotent phenotype of gastric cancer cells by binding to PTEN promoter. J Hematol Oncol. 2018 Jan 15;11(1):9.

26. Pellecchia $S$, Sepe $R$, Decaussin-Petrucci $M$, et al. The long non-coding RNA Prader Willi/Angelman Region RNA5 (PAR5) is downregulated in anaplastic thyroid carcinomas where it acts as a tumor suppressor by reducing $\mathrm{EZH} 2$ activity. Cancers (Basel). 2020;12(1):E235.

27. Fan DC, Zhao YR, Qi H, Hou JX, Zhang TH. MiRNA-506 presents multiple tumor suppressor activities by targeting EZH2 in nasopharyngeal carcinoma. Auris Nasus Larynx. 2020 Jan 10;S0385-S8146(19)30941-1. 
28. Krill L, Deng W, Eskander R, et al. Overexpression of enhance of Zeste homolog 2 (EZH2) in endometrial carcinoma: An NRG Oncology/ Gynecologic Oncology Group Study. Gynecol Oncol. 2020;156(2):423-9.

29. Sun C, Zhao C, Li S, et al. EZH2 Expression is increased in BAP1-mutant renal clear cell carcinoma and is related to poor prognosis. J Cancer. 2018;9(20): 3787-96.

30. Sashida G, Iwama A. Multifaceted role of the polycomb-group gene EZH2 in hematological malignancies. Int J Hematol. 2017;105(1):23-30.

31. Bödör C, O'Riain C, Wrench D, Matthews J, lyengar S, Tayyib H, Calaminici M, Clear A, labal S, Quentmeier H, Drexler HG, Montoto S, Lister AT, Gribben JG, Matolcsy A, Fitzgibbon J. EZH2 Y641 mutations in follicular lymphoma. Leukemia. 2011;25(4):726-9.

32. Yap DB, Chu J, Berg T, Schapira M, Cheng SW, Moradian A, Morin RD, Mungall AJ, Meissner B, Boyle M, Marquez VE, Marra MA, Gascoyne RD, Humphries RK, Arrowsmith CH, Morin GB, Aparicio SA. Somatic mutations at EZH2 Y641 act dominantly through a mechanism of selectively altered PRC2 catalytic activity, to increase H3K27 trimethylation. Blood. 2011;117(8): 2451-9.

33. Zhang $\mathrm{Q}, \mathrm{Han} \mathrm{Q}, \mathrm{Zi}$ J, et al. Mutations in $\mathrm{EZH} 2$ are associated with poor prognosis for patients with myeloid neoplasms. Genes Dis. 2019;6(3):276-81.

34. Xia L, Zhu X, Zhang L, Xu Y, Chen G, Luo J. EZH2 enhances expression of CCL5 to promote recruitment of macrophages and invasion in lung cancer [published online ahead of print, 2019 Dec 19]. Biotechnol Appl Biochem. 2019;10.1002/bab.1875

35. Zingg D, Debbache J, Schaefer SM, et al. The epigenetic modifier EZH2 controls melanoma growth and metastasis through silencing of distinct tumour suppressors. Nat Commun. 2015;6:6051. Published 2015 Jan 22.

36. Ma J, Zhang J, Weng YC, Wang JC. EZH2-mediated microRNA-139-5p regulates epithelial-mesenchymal transition and lymph node metastasis of pancreatic cancer. Mol Cell. 2018;41(9):868-80.

37. Lu C, Han HD, Mangala LS, Ali-Fehmi R, Newton CS, Ozbun L, Armaiz-Pena GN, Hu W, Stone RL, Munkarah A, Ravoori MK, Shahzad MM, Lee JW, Mora E, Langley RR, Carroll AR, Matsuo K, Spannuth WA, Schmandt R, Jennings NB, Goodman BW, Jaffe RB, Nick AM, Kim HS, Guven EO, Chen YH, Li LY, Hsu MC, Coleman RL, Calin GA, Denkbas EB, Lim JY, Lee JS, Kundra V, Birrer MJ, Hung MC, Lopez-Berestein G, Sood AK. Regulation of tumor angiogenesis by EZH2. Cancer Cell. 2010;18(2):185-97.

38. Mallen-St Clair J, Soydaner-Azeloglu R, Lee KE, Taylor L, Livanos A, PylayevaGupta Y, Miller G, Margueron R, Reinberg D, Bar-Sagi D. EZH2 couples pancreatic regeneration to neoplastic progression. Genes Dev. 2012;26(5): 439-44.

39. Ntziachristos $P$, Tsirigos A, Van Vlierberghe P, Nedjic J, Trimarchi T, Flaherty MS, Ferres-Marco D, da Ros V, Tang Z, Siegle J, Asp P, Hadler M, Rigo I, De Keersmaecker K, Patel J, Huynh T, Utro F, Poglio S, Samon JB, Paietta E, Racevskis J, Rowe JM, Rabadan R, Levine RL, Brown S, Pflumio F, Dominguez M, Ferrando A, Aifantis I. Genetic inactivation of the polycomb repressive complex 2 in T cell acute lymphoblastic leukemia. Nat Med. 2012;18(2):298-301.

40. Wang Y, Hou N, Cheng X, Zhang J, Tan X, Zhang C, Tang Y, Teng Y, Yang X. Ezh2 acts as a tumor suppressor in Kras-driven lung adenocarcinoma. Int J Biol Sci. 2017 May 16;13(5):652-9.

41. Shimizu T, Kubovcakova L, Nienhold R, et al. Loss of Ezh2 synergizes with JAK2-V617F in initiating myeloproliferative neoplasms and promoting myelofibrosis. J Exp Med. 2016;213(8):1479-96.

42. Peng D, Kryczek I, Nagarsheth N, Zhao L, Wei S, Wang W, Sun Y, Zhao E, Vatan L, Szeliga W, Kotarski J, Tarkowski R, Dou Y, Cho K, Hensley-Alford S, Munkarah A, Liu R, Zou W. Epigenetic silencing of TH1-type chemokines shapes tumour immunity and immunotherapy. Nature. 2015 Nov 12; 527(7577):249-53.

43. Dangaj $\mathrm{D}$, Bruand $\mathrm{M}$, Grimm AJ, et al. Cooperation between constitutive and inducible chemokines enables $T$ cell engraftment and immune attack in solid tumors. Cancer Cell. 2019;35(6):885-900.

44. Yin Y, Qiu S, Li X, Huang B, Xu Y, Peng Y. EZH2 suppression in glioblastoma shifts microglia toward M1 phenotype in tumor microenvironment. J Neuroinflammation. 2017:14(1):220. Published 2017 Nov 13.

45. Karantanos T, Chistofides A, Barhdan K, Li L, Boussiotis VA. Regulation of T cell differentiation and function by EZH2. Front Immunol. 2016;7:172.

46. Zhao E, Maj T, Kryczek I, Li W, Wu K, Zhao L, Wei S, Crespo J, Wan S, Vatan L, Szeliga W, Shao I, Wang Y, Liu Y, Varambally S, Chinnaiyan AM, Welling TH, Marquez V, Kotarski J, Wang H, Wang Z, Zhang Y, Liu R, Wang G, Zou W. Cancer mediates effector $T$ cell dysfunction by targeting microRNAs and EZH2 via glycolysis restriction. Nat Immunol. 2016 Jan;17(1):95-103.
47. Li H, Wen Y, Wu S, et al. Epigenetic modification of enhancer of zeste homolog 2 modulates the activation of dendritic cells in allergen immunotherapy. Int Arch Allergy Immunol. 2019;180(2):120-7.

48. Wang D, Quiros J, Mahuron K, Pai CC, Ranzani V, Young A, Silveria S, Harwin T, Abnousian A, Pagani M, Rosenblum MD, Van Gool F, Fong L, Bluestone JA, DuPage M. Targeting EZH2 reprograms intratumoral regulatory T cells to enhance cancer immunity. Cell Rep. 2018 Jun 12;23(11):3262-74.

49. Tumes DJ, Onodera A, Suzuki A, et al. The polycomb protein Ezh2 regulates differentiation and plasticity of CD4(+) T helper type 1 and type 2 cells. Immunity. 2013;39(5):819-32.

50. Yin J, Leavenworth JW, Li Y, et al. Ezh2 regulates differentiation and function of natural killer cells through histone methyltransferase activity. Proc Natl Acad Sci U S A. 2015;112(52):15988-93.

51. Tao $T$, Chen M, Jiang $R$, et al. Involvement of EZH2 in aerobic glycolysis of prostate cancer through miR-181b/HK2 axis. Oncol Rep. 2017:37(3):1430-6.

52. Yiew NKH, Greenway C, Zarzour A, et al. Enhancer of zeste homolog 2 (EZH2) regulates adipocyte lipid metabolism independent of adipogenic differentiation: role of apolipoprotein E. J Biol Chem. 2019;294(21):8577-91.

53. Ahmad F, Patrick S, Sheikh T, et al. Telomerase reverse transcriptase (TERT) enhancer of zeste homolog 2 (EZH2) network regulates lipid metabolism and DNA damage responses in glioblastoma. J Neurochem. 2017;143(6): $671-83$.

54. Sun J, Cai X, Yung MM, et al. miR-137 mediates the functional link between C-Myc and EZH2 that regulates cisplatin resistance in ovarian cancer. Oncogene. 2019;38(4):564-80.

55. Liu X, Lu X, Zhen F, et al. LINC00665 induces acquired resistance to Gefitinib through recruiting EZH2 and activating PI3K/AKT pathway in NSCLC. Mol Ther Nucleic Acids. 2019;16:155-61.

56. Wu Y, Zhang Z, Cenciarini ME, et al. Tamoxifen resistance in breast cancer is regulated by the EZH2-ERa-GREB1 transcriptional axis. Cancer Res. 2018; 78(3):671-84.

57. ClinicalTrials. https://clinicaltrials.gov/. Accessed 19 Apr 2020.

58. Miranda TB, Cortez CC, Yoo CB, et al. DZNep is a global histone methylation inhibitor that reactivates developmental genes not silenced by DNA methylation. Mol Cancer Ther. 2009;8(6):1579-88.

59. Fioravanti R, Stazi G, Zwergel C, Valente S, Mai A. Six years (2012-2018) of researches on catalytic EZH2 inhibitors: the boom of the 2-pyridone compounds. Chem Rec. 2018:18(12):1818-32.

60. McCabe MT, Ott HM, Ganji G, et al. EZH2 inhibition as a therapeutic strategy for lymphoma with EZH2-activating mutations. Nature. 2012;492(7427):108-12.

61. Yap TA, Winter JN, Giulino-Roth $L$, et al. Phase I study of the novel enhancer of zeste homolog 2 (EZH2) inhibitor GSK2816126 in patients with advanced hematologic and solid tumors. Clin Cancer Res. 2019;25(24):7331-9.

62. Huang S, Wang Z, Zhou J, et al. EZH2 inhibitor GSK126 suppresses antitumor immunity by driving production of myeloid-derived suppressor Cells. Cancer Res. 2019;79(8):2009-20.

63. Knutson SK, Wigle TJ, Warholic NM, et al. A selective inhibitor of EZH2 blocks H3K27 methylation and kills mutant lymphoma cells. Nat Chem Biol. 2012:8(11):890-6.

64. Qi W, Chan H, Teng L, et al. Selective inhibition of Ezh2 by a small molecule inhibitor blocks tumor cells proliferation. Proc Natl Acad Sci U S A. 2012 109(52):21360-5.

65. Verma SK, Tian X, LaFrance LV, et al. Identification of potent, selective, cellactive inhibitors of the histone lysine methyltransferase EZH2. ACS Med Chem Lett. 2012:3(12):1091-6.

66. Knutson SK, Kawano S, Minoshima Y, et al. Selective inhibition of EZH2 by EPZ-6438 leads to potent antitumor activity in EZH2-mutant non-Hodgkin lymphoma. Mol Cancer Ther. 2014;13(4):842-54.

67. Knutson SK, Warholic NM, Wigle TJ, et al. Durable tumor regression in genetically altered malignant rhabdoid tumors by inhibition of methyltransferase EZH2. Proc Natl Acad Sci U S A. 2013;110(19):7922-7.

68. Silvia Stacchiotti, Patrick Schoffski, Robin Jones, Mark Agulnik, Victor Manuel Villalobos, Thierry Marie Jahan, Tom Wei-Wu Chen, Antoine Italiano, George D. Demetri, Gregory Michael Cote, Rashmi Chugh, Steven Attia, Abha A. Gupta, Elizabeth T. Loggers, Brian Van Tine, Laura Sierra, Jay Yang, Anand Rajarethinam, and Mrinal M. Gounder. Safety and efficacy of tazemetostat, a first-in-class EZH2 inhibitor, in patients (pts) with epithelioid sarcoma (ES) (NCT02601950). J Clin Oncol 2019 37:15_suppl, 11003-11003.

69. NDA 211723 :Epizyme briefing information for the December 18, 2019 meeting of the oncologic drugs advisory committee. https://www.fda.gov/ media/133575/download. Accessed 19 June 2020. 
70. Italiano A. Targeting epigenetics in sarcomas through EZH2 inhibition. J Hematol Oncol. 2020;13(1):33.

71. Publications and data presentations Of epizyme. http://www.epizyme.com/ wp-content/uploads/2019/11/ICML_2019_FL_Morschhauser_105_oralpresentation_FINAL06212019.pdf. Accessed 19 Apr 2020.

72. Campbell JE, Kuntz KW, Knutson SK, et al. EPZ011989, a potent, orallyavailable EZH2 inhibitor with robust in vivo activity. ACS Med Chem Lett. 2015;6(5):491-5.

73. Vaswani RG, Gehling VS, Dakin LA, et al. Identification of (R)-N-((4-Methoxy6-methyl-2-oxo-1,2-dihydropyridin-3-yl)methyl)-2-methyl-1-(1-(1-(2,2,2trifluoroethyl)piperidin-4-yl)ethyl)-1H-indole-3-carboxamide (CPI-1205), a potent and selective inhibitor of histone methyltransferase $\mathrm{EZH} 2$, suitable for phase I clinical trials for B-cell lymphomas. J Med Chem. 2016;59(21): 9928-41.

74. Gehling VS, Vaswani RG, Nasveschuk CG, et al. Discovery, design, and synthesis of indole-based EZH2 inhibitors. Bioorg Med Chem Lett. 2015; 25(17):3644-9.

75. Song X, Gao T, Wang N, et al. Selective inhibition of EZH2 by ZLD1039 blocks H3K27 methylation and leads to potent anti-tumor activity in breast cancer. Sci Rep. 2016;6:20864.

76. Kung PP, Bingham P, Brooun A, et al. Optimization of orally bioavailable enhancer of zeste homolog $2(\mathrm{EZH} 2)$ inhibitors using ligand and propertybased design strategies: identification of development candidate (R)-5,8Dichloro-7-(methoxy(oxetan-3-yl)methyl)-2-((4-methoxy-6-methyl-2-oxo-1,2 dihydropyridin-3-yl)methyl)-3,4-dihydroisoquinolin-1(2H)-one (PF-06821497). J Med Chem. 2018;61(3):650-65.

77. Shen $\mathrm{X}$, Liu Y, Hsu YJ, et al. EZH1 mediates methylation on histone $\mathrm{H3}$ lysine 27 and complements EZH2 in maintaining stem cell identity and executing pluripotency. Mol Cell. 2008;32(4):491-502.

78. Konze KD, Ma A, Li F, et al. An orally bioavailable chemical probe of the lysine methyltransferases EZH2 and EZH1. ACS Chem Biol. 2013;8(6):1324-34.

79. Xu B, On DM, Ma A, et al. Selective inhibition of EZH2 and EZH1 enzymatic activity by a small molecule suppresses MLL-rearranged leukemia. Blood. 2015;125(2):346-57.

80. Honma D, Kanno O, Watanabe J, et al. Novel orally bioavailable EZH1/2 dual inhibitors with greater antitumor efficacy than an EZH2 selective inhibitor. Cancer Sci. 2017;108(10):2069-78.

81. Hidalgo I, Herrera-Merchan A, Ligos JM, et al. Ezh1 is required for hematopoietic stem cell maintenance and prevents senescence-like cell cycle arrest. Cell Stem Cell. 2012;11(5):649-62.

82. Kim W, Bird GH, Neff T, et al. Targeted disruption of the EZH2-EED complex inhibits EZH2-dependent cancer. Nat Chem Biol. 2013;9(10):643-50.

83. Kong $X$, Chen $L$, Jiao $L$, et al. Astemizole arrests the proliferation of cancer cells by disrupting the EZH2-EED interaction of polycomb repressive complex 2. J Med Chem. 2014;57(22):9512-21.

84. Chen H, Gao S, Li J, et al. Wedelolactone disrupts the interaction of EZH2EED complex and inhibits PRC2-dependent cancer. Oncotarget. 2015;6(15): 13049-59.

85. Zhu MR, Du DH, Hu JC, et al. Development of a high-throughput fluorescence polarization assay for the discovery of EZH2-EED interaction inhibitors. Acta Pharmacol Sin. 2018:39(2):302-10.

86. Zhang KL, Shen QQ, Fang YF, Sun YM, Ding J, Chen Y. AZD9291 inactivates the PRC2 complex to mediate tumor growth inhibition [published correction appears in Acta Pharmacol Sin. 2020 Feb 14;]. Acta Pharmacol Sin. 2019:40(12):1587-95.

87. Qi W, Zhao K, Gu J, et al. An allosteric PRC2 inhibitor targeting the H3K27me3 binding pocket of EED. Nat Chem Biol. 2017;13(4):381-8.

88. Wan L, Xu K, Wei Y, et al. Phosphorylation of EZH2 by AMPK suppresses PRC2 methyltransferase activity and oncogenic function. Mol Cell. 2018; 69(2):279-91.

89. Wang $X$, Cao W, Zhang J, et al. A covalently bound inhibitor triggers EZH2 degradation through CHIP-mediated ubiquitination. EMBO J. 2017;36(9): $1243-60$.

90. Li Z, Hou P, Fan D, et al. The degradation of EZH2 mediated by IncRNA ANCR attenuated the invasion and metastasis of breast cancer. Cell Death Differ. 2017;24(1):59-71.

91. Jin X, Yang C, Fan P, et al. CDK5/FBW7-dependent ubiquitination and degradation of $\mathrm{EZH} 2$ inhibits pancreatic cancer cell migration and invasion. J Biol Chem. 2017;292(15):6269-80.
92. Lu W, Liu S, Li B, et al. SKP2 loss destabilizes EZH2 by promoting TRAF6mediated ubiquitination to suppress prostate cancer. Oncogene. 2017; 36(10):1364-73.

93. Zhang $P$, Xiao Z, Wang $S$, et al. ZRANB1 is an EZH2 deubiquitinase and a potential therapeutic target in breast cancer. Cell Rep. 2018;23(3):823-37.

94. Goswami S, Apostolou I, Zhang J, et al. Modulation of EZH2 expression in T cells improves efficacy of anti-CTLA-4 therapy. J Clin Invest. 2018;128(9): 3813-8.

95. Zhou L, Mudianto T, Ma X, Riley R, Uppaluri R. Targeting EZH2 enhances antigen presentation, antitumor immunity, and circumvents anti-PD-1 resistance in head and neck cancer. Clin Cancer Res. 2020;26(1):290-300.

96. Knutson SK, Warholic NM, Johnston LD, et al. Synergistic anti-tumor activity of EZH2 inhibitors and glucocorticoid receptor agonists in models of germinal center non-Hodgkin lymphomas. PLoS One. 2014;9(12):e111840.

97. Tazemetostat in combination with doxorubicin as frontline therapy for advanced epithelioid sarcoma. https://clinicaltrials.gov/ct2/show/NCT04204 941?term=Tazemetostat\&draw=9\&rank=10. Accessed 19 Apr 2020.

98. Sarkozy C, Morschhauser F, Dubois S, et al. A LYSA phase lb study of tazemetostat (EPZ-6438) plus R-CHOP in patients with newly diagnosed diffuse large $\mathrm{B}$-cell lymphoma (DLBCL) with poor prognosis features [published online ahead of print, 2020 Mar 2]. Clin Cancer Res. 2020;10. 1158/1078-0432.CCR-19-3741.

99. Katona BW, Liu Y, Ma A, Jin J, Hua X. EZH2 inhibition enhances the efficacy of an EGFR inhibitor in suppressing colon cancer cells. Cancer Biol Ther. 2014;15(12):1677-87.

100. Yang Y, Zhu F, Wang Q, Ding Y, Ying R, Zeng L. Inhibition of EZH2 and EGFR produces a synergistic effect on cell apoptosis by increasing autophagy in gastric cancer cells. Onco Targets Ther. 2018;11:8455-63.

101. Gong H, Yuan Y, Li Y, Zhang H, Li Y, Li W, Wang P, Shi R, Liu C, Cui L, Liu H, Chen J. Role of EZH2 inhibitor combined with gefitinib in EGFR-TKIs resistant lung cancer cells. Zhongguo Fei Ai Za Zhi. 2019 May 20;22(5):255-63.

102. Hirukawa A, Singh S, Wang J, et al. Reduction of global H3K27me3 enhances HER2/ErbB2 targeted therapy. Cell Rep. 2019;29(2):249-57.

103. Huang $X$, Yan J, Zhang $M$, et al. Targeting epigenetic crosstalk as a therapeutic strategy for EZH2-aberrant solid tumors. Cell. 2018;175(1):186-99.

\section{Publisher's Note}

Springer Nature remains neutral with regard to jurisdictional claims in published maps and institutional affiliations.

Ready to submit your research? Choose BMC and benefit from:

- fast, convenient online submission

- thorough peer review by experienced researchers in your field

- rapid publication on acceptance

- support for research data, including large and complex data types

- gold Open Access which fosters wider collaboration and increased citations

- maximum visibility for your research: over $100 \mathrm{M}$ website views per year

At $\mathrm{BMC}$, research is always in progress.

Learn more biomedcentral.com/submission 